\section{Assisted dying in Canada}

I wish to respond to a letter written by Johnston $^{1}$ that appeared in the Dec. 11, 2012 , issue of CMAJ. In his letter, Johnston provides a false portrait of medically assisted dying.

I wholeheartedly agree with Johnston that suicide is a major public health problem in our society - however that is not germane to this discussion. Advocates of the right to die with dignity deliberately distance themselves from the word suicide because it is simply not what they are talking about. Suicide is about individuals, generally with mental health issues, who tragically cut their lives short. There is a world of difference between suicide and assisted dying. Individuals who know they are going to die face the prospect of horrific suffering and are simply asking for the right to humane assistance to die peacefully. Johnston paints an Orwellian picture of victims being taken to doctors' offices where they are coerced to die against their will. Frankly, I don't know of any physician - nor can I imagine one - who would be complicit in such an act. The picture Johnston paints is a caricature of the real situation, where compassionate health care providers work with patients who are suffering greatly and are asking for assistance to die as a very last resort. Publications that have purported to show coercion and abuse in other countries ${ }^{2}$ have been shown to be seriously flawed and riddled with errors.

I find it in keeping with the rest of his letter that the well-researched, wellreasoned and well-written 300-plus page decision of Justice Smith of the BC Supreme Court ${ }^{4}$ is summarily dismissed. After hearing expert testimony from Canada and around the world and seeing experts from both sides crossexamined, Justice Smith weighed the evidence and reached a carefully considered conclusion. Anyone who takes the time to read her decision with an open mind will undoubtedly reach the same conclusion.

How will these laws affect our profession? A fascinating study out of Ore- gon reports that 5 years after Oregon's Death With Dignity Act was passed, nurses characterized doctors as being more knowledgeable about pain medications, more competent in caring for hospice patients and more interested in caring for hospice patients. ${ }^{5}$

Although peer reviewed studies show that safeguards work ${ }^{6}$ and reporting tells us that over two-thirds of requests for euthanasia in the Netherlands are declined, ${ }^{7}$ some worry about the adequacy of safeguards and the criteria for eligibility. We should listen and ensure we address these concerns in any legislation that is written. But when others argue that there are no possible safeguards that we could put in place to make this process safe, we know they have left reason behind. We should be very wary of Johnston's words.

\section{Gregory Robinson MD}

Board member, Dying with Dignity

Canada, Toronto, Ont.

\section{References}

1. Johnston W. More on assisted suicide [letter]. CMAJ 2012; 184:2018.

2. Pereira J. Legalizing euthanasia or assisted suicide, the illusion of safeguards and controls. Curr Oncol 2011;18: e38-45

3. Downie J, Chambaere K, Bernheim JL. Pereira's attack on legalizing euthanasia or assisted suicide: smoke and mirrors. Curr Oncol 2012;19:133-8.

4. Carter v. Canada (Attorney General), 2012 BCSC886. No. S112688. Available: www.dying withdignity.ca/database_Canada_AG_2012_BCSC _886.pdf (accessed 2013 Jan. 31).

5. Goy ER, Jackson A, Harvath T, et al. Oregon hospice nurses and social workers' assessment of physician progress in palliative care over the past 5 years. Palliat Support Care 2003;1:215- 19.

6. Battin MP, van der Heide A, Ganzini L. Legal physician-assisted dying in Oregon and the Netherlands: evidence concerning the impact on patients in "vulnerable" groups. J Med Ethics 2007;33:591-7.

7. FAQ euthanasia 2010: the termination of life on request and Assisted Suicide (review procedures) Act in practice. The Hague (Netherlands): Ministry of Foreign Affairs; 2010.

CMAJ 2013. DOI:10.1503/cmaj.113-2107

\section{Opioid abuse}

I agree with Fletcher and Tsuyuki who, in their recent CMAJ editorial, caution against provincial drug formularies adding generic oxycodone to the list of products eligible for funding. ${ }^{1}$ However, the authors are far too generous in their treatment of Purdue Pharma

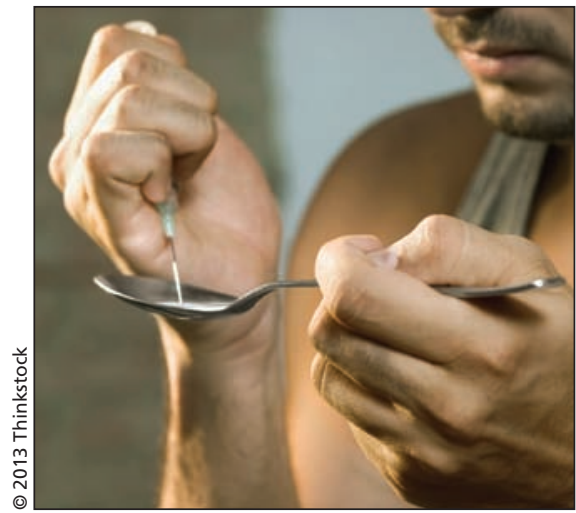

Canada - the makers of the original and tamper-resistant forms of oxycodone. Purdue's aggressive marketing campaign was partly responsible for the widespread use and subsequent abuse of oxycodone. ${ }^{2}$ The tamper-resistant version of oxycodone was available in the United States in April 2010. In Canada, Purdue only introduced it in March 2012 - just prior to the expiration of the patent on the original version. ${ }^{3}$ Restricting which version of oxycodone is covered on provincial formularies may not deter overall abuse of opioids. Tamper-resistant oxycodone may be less abused, but there is evidence from the US that people are switching to other opioids, with heroin being the drug of choice. ${ }^{4}$

\section{Joel Lexchin MD}

Emergency physician, University Health Network, Toronto, Ont.

\section{References}

1. Fletcher J, Tsuyuki R. Don't tamper with oxycodone. CMAJ 2013;185:107.

2. Lexchin J, Kohler JC. The danger of imperfect regulation: OxyContin use in the United States and Canada. Int J Risk Saf Med 2011;23:233-40.

3. Diebel L. Critics allege OxyNEO was introduced in Canada because of impending patent expiry. Toronto Star 2012 Apr. 22; Sect A: 1

4. Cicero TJ, Ellis MS, Surratt HL. Effect of abusedeterrent formulation of OxyContin. $N$ Engl J Med 2012;367:187-9.

CMAJ 2013. DOI:10.1503/cmaj.113-2108

Some letters have been abbreviated for print. See www.cmaj.ca for full versions and competing interests. 